\title{
PENGARUH MOTIVASI, FAKTOR KELUARGA, LINGKUNGAN KAMPUS DAN AKTIF BERORGANISASI TERHADAP PRESTASI AKADEMIK
}

\author{
Minhayati Saleh
}

\begin{abstract}
Abstrak
Tujuan utama penelitian ini adalah: Untuk mengetahui pengaruh motivasi, faktor keluarga, lingkungan kampus dan aktif organisasi terhadap prestasi akademik mahasiswa Fakultas Ilmu Tarbiyah dan Keguruan IAIN Walisongo Semarang. Penelitian ini menggunakan metode survei dengan menggunakan kuesioner yang diedarkan ke responden. Populasi adalah seluruh mahasiswa Fakultas Ilmu Tarbiyah dan Keguruan IAIN Walisongo Semarang yang berada pada semester 3 ke atas. Untuk pemilihan sampel digunakan teknik simple random sampling. Analisa data menggunakan statistik deskriptif dan analisis regresi berganda. Hasil penelitian menunjukkan bahwa variabel bebas yang berpengaruh positif dan signifikan terhadap prestasi akademik adalah motivasi, faktor keluarga, lingkungan kampus dan aktif organisasi berpengaruh positif dan signifikan terhadap prestasi akademik mahasiswa FITK.
\end{abstract}

Kata kunci: prestasi akademik, motivasi, faktor keluarga, lingkungan kampus 


\section{PENDAHULUAN}

Mengingat sangat pentingnya pendidikan bagi kehidupan, pendidikan harus dilaksanakan sebaik-baiknya dalam segala lapisan masyarakat sehingga memperoleh hasil yang maksimal. Menurut Hamalik, pendidikan dikatakan berkualitas bila proses belajar mengajar dapat berjalan dengan lancar, efektif, efisien dan ada interaksi antara komponen- komponen yang terkandung dalam sistem pengajaran yaitu tujuan pendidikan dan pengajaran, peserta didik, tenaga kependidikan atau guru, kurikulum, strategi pembelajaran, media pengajaran dan evaluasi pengajaran ${ }^{1}$.

Fokus utama dalam dunia pendidikan adalah manusia dalam hal ini adalah peserta didik karena dengan adanya pendidikan peserta didik didorong untuk terlibat dalam proses mengubah kehidupannya kearah yang lebih baik, mengembangkan kepercayaan diri sendiri, mengembangkan rasa ingin tahu, serta meningkatkan pengetahuan dan ketrampilan yang telah dimilikinya, sehingga dapat berfungsi untuk peningkatan kualitas hidup pribadi dan masyarakat.

Pada tingkat pendidikan tinggi, mahasiswa dituntut untuk aktif dalam proses belajar mengajar melalui media yang ada, seperti perpustakaan, jurnal, maupun internet. Hampir semua tugas yang diberikan di pendidikan tinggi umumnya menuntut mahasiswa untuk mencari literatur lain dan mengembangkan pola pikirnya sendiri guna penyelesaian tugas secara efektif.

Persyaratan akademik di pendidikan tinggi bukan sekedar mengikuti perkuliahan saja, tetapi ada ketentuan-ketentuan lain seperti persentase kehadiran dalam perkuliahan, penyelesaian tugas-tugas, dan ikut aktif dalam kegiatan akademik lainnya (diskusi, presentasi, mengikuti ujian, kuis). Keberhasilan mahasiswa dalam bidang akademik ditandai dengan prestasi akademik yang dicapai, ditunjukkan melalui Indeks Prestasi (IP) maupun Indeks Prestasi Kumulatif (IPK) serta ketepatan dalam menyelesaikan studi.

Indeks prestasi dijadikan sebagai tolok ukur penguasaan ak-

${ }^{1}$ Oemar Hamalik. 2006. Proses Belajar Mengajar. Hal: 77, Jakarta: Bumi Aksara 
ademik mahasiswa. Semakin baik penguasaan akademik mahasiswa maka prestasi yang diperolehpun akan baik pula. Pencapaian prestasi akademik mahasiswa dipengaruhi oleh berbagai faktor baik faktor dari dalam diri mahasiswa (faktor internal) maupun faktor dari luar diri mahasiswa (faktor eksternal).

Menurut Syah², faktor-faktor yang mempengaruhi prestasi akademik mahasiswa terbagi menjadi tiga yaitu faktor internal, faktor eksternal, dan faktor pendekatan belajar. Faktor internal terdiri dari aspek fisiologis (status gizi, kesehatan, dan kebiasaan sarapan pagi) dan aspek psikologis (inteligensi, sikap, bakat, minat, dan motivasi). Faktor eksternal terdiri dari lingkungan sosial (pendidikan ayah, pendidikan ibu, keadaan ekonomi orang tua, guru, teman-teman sepermainan, dan masyarakat) dan lingkungan non-sosial (lingkungan sekolah dan lingkungan tempat tinggal).

Prestasi mahasiswa merupakan pencerminan dari potensi mahasiswa itu sendiri yang dipengaruhi oleh kualitas proses belajar mengajar (PBM). Dalam PBM minimal ada tiga peubah yang sangat berpengaruh, yaitu: kualitas tenaga pengajar (dosen), kurikulum dan sasaran serta prasarana termasuk laboratorium. Prestasi mahasiswa dapat dilihat dari IPK (indeks prestasi kumulatif) yang mengukur mahasiswa secara akademik. Nilai IPK dipengaruhi oleh kualitas tenaga pengajar yang diukur melalui tingkat pendidikan formal yang ditamatkan, penguasaan metode mengajar dan penguasaan materi yang diajarkan. Prestasi mahasiswa juga dapat dilihat dari prestasi di bidang lain misal dibidang olahraga, kesenian atau musik, bahasa dan lain-lain².

Hasil wawancara dengan beberapa mahasiswa dari studi awal di lapangan didapatkan suatu pengalaman menarik, yaitu ada mahasiswa yang tidak mempunyai catatan kuliah sendiri karena mahasiswa tersebut cukup puas dengan belajar dari fotokopi catatan

2 Syah, Muhibbin. 2010. Psikologi Pendidikan. Bandung: PT Remaja Rosdakarya

${ }^{3}$ Sampoerno, P.D., 2002, Analisis Kualitas Mahasiswa dalam Pencapaian Pendidikan dengan Menggunakan Partial Least Square, Tesis, Program Pascasarja Institut Pertanian Bogor. 
temannya, ada sebagian mahasiswa tidak mempersiapkan diri terhadap materi kuliah yang akan diajarkan dosen sehingga terkesan sangat asing karena mahasiswa belum pernah mempelajari sebelumnya, ada sebagian mahasiswa yang tidak mengulang kembali materi kuliah yang telah diberikan dosen sesegera mungkin dengan alasan masih banyak kesempatan di waktu lain untuk mengulang materi tersebut, ada sebagian mahasiswa yang belajar bila menjelang ujian saja baik tengah semester maupun semesteran atau hanya bila ada tugas dari dosen yang memerlukan pemahaman.

Hasil penelitian kusumastuti bahwa tinggi rendahnya prestasi belajar siswa juga berhubungan dengan tingkat pendidikan dan tingkat penghasilan orang tua. Karena dengan adanya tingkat pendidikan dan tingkat penghasilan yang tinggi diharapkan orang tua selain akan memberikan perhatian dan kepedulian terhadap kegiatan belajar siswa juga akan dapat memenuhi fasilitas belajar siswa dan biaya sekolah lainnya, yang pada gilirannya dapat memotivasi siswa untuk meningkatkan prestasi belajarnya. Sebaliknya dengan tingkat pendidikan yang rendah dan tingkat penghasilan yang rendah dari orang tua maka selain dapat mengurangi perhatian dan kepedulian orang tua terhadap kegiatan belajar siswa juga akan dapat mengurangi pemenuhan kebutuhan atau fasilitas belajar siswa dan biaya sekolah lainnya. Sehingga akan menurunkan motivasi belajar yang pada gilirannya akan mengurangi prestasi belajar siswa ${ }^{4}$.

Sedangkan penelitian yang dilakukan oleh Yuniah dengan Metode CHAID (Chi-Square Automatic Interaction Detection), Hasil penelitiannya dari hasil dendogram diketahui faktor-faktor yang berpengaruh terhadap prestasi akademik yaitu jumlah nilai UAN, kepemilikan sahabat, metode belajar, jalur masuk IPB, jenis kelamin,

${ }^{4}$ Kusumastuti, Tri Laswi. 2010. Hubungan antara Tingkat Pendidikan dan Penghasilan Orang Tua dengan Prestasi Belajar IPA Semester Satu Siswa Kelas Tujuh SMP Cinde Semarang Tahun Pelajaran 2010/2011.Penelitian Tindakan Kelas. Semarang. Diakses 23 April 2011 dalam situs web: http://www.scribd.com/doc/55874141/Hubungan-Antara-Tingkat-Pendidikan-Dan-Penghasilan-Orang-Tua. 
pengaruh 4 orang/kamar dalam asrama dan pekerjaan orang tua ${ }^{5}$.

Penelitian ini mencoba untuk mengetahui faktor-faktor yang paling berpengaruh terhadap prestasi akademik mahasiswa FITK. Faktor-faktor yang diperkirakan dapat mempengaruhi prestasi akademik mahasiswa adalah motivasi, faktor keluarga, lingkungan kampus, dan aktif organisasi.

Rumusan Masalah:

1. Adakah pengaruh motivasi terhadap prestasi akademik mahasiswa FITK?

2. Adakah pengaruh faktor keluarga terhadap prestasi akademik mahasiswa FITK?

3. Adakah pengaruh lingkungan kampus terhadap prestasi akademik mahasiswa FITK?

4. Adakah pengaruh aktif berorganisasi terhadap prestasi akademik mahasiswa FITK?

\section{KAJIAN PUSTAKA}

\section{Prestasi Akademik}

Kata prestasi berasal dari bahasa Belanda yaitu prestatie, sedangkan dalam bahasa Inggris istilah prestasi atau achievement dalam Kamus Lengkap Psikologi (Kartini Kartono \& Dali Gulo, 2006) didefinisikan sebagai pencapaian atau hasil yang dicapai; sesuatu yang telah dicapai; satu tingkat khusus dari kesuksesan karena mempelajari tugas-tugas, atau tingkat tertentu dari kecakapan/ keahlian dalam tugas-tugas sekolah atau akademis; satu tingkat khusus perolehan atau hasil keahlian dalam karya akademis yang dinilai oleh guru-guru lewat tes-tes yang dibakukan, atau lewat kombinasi kedua hal tersebut.

Dalam kamus populer dinyatakan bahwa: prestasi adalah apa yang telah diciptakan, hasil pekerjaan, hasil yang menyenangkan

5 Yuniah.2006. Faktor-Faktor yang Berpengaruh Terhadap Prestasi Akademik Mahasiswa Tpb IPB Dengan Metode Chaid. Departemen Statistika Fakultas Matematika Dan Ilmu Pengetahuan Alam. Institut Pertanian Bogor 
hati yang diperoleh dengan jalan keuletan kerja ${ }^{6}$. Sedangkan dalam kamus bahasa Indonesia bahwa: prestasi adalah hasil yang telah dicapai (dan yang telah dilakukan atau dikerjakan) ${ }^{7}$.

Secara garis besar, faktor-faktor yang mempengaruhi keberhasilan mahasiswa dalam pendidikan menurut Munthe dalam Halim $^{8}$ adalah:

1. Faktor intelektual seperti masalah belajar, bakat, dankecerdasan.

2. Faktor non intelektual seperti sosial, emosional, jenis kelamin, kesehatan, keuangan, pengembangan pribadi, keluarga, pemanfaatan waktu luang, agama, dan akhlak.

Menurut Munandar dalam Sampoerno, kualitas mahasiswa banyak dipengaruhi oleh berbagai faktor, antara lain:

1. Latar belakang keluarga; dukungan orang tua, taraf sosial ekonomi orang tua.

2. Lingkungan belajar di rumah; sarana dan prasarana yang tersedia.

3. Lingkungan kampus dan dosennya; mampu bersosialisasi.

4. Motivasi; minat untuk berprestasi, keuletan 9.

\section{Faktor-Faktor Yang Mempengaruhi Prestasi Akademik}

Tujuan pendidikan pada dasarnya adalah mempersiapkan generasi agar dapat menjalani kehidupan dan dapat memecahkan masalah-masalah yang akan dihadapi. Tujuan pendidikan dapat

${ }^{6}$ S.F. Habeyb. 1983. Kamus Populer. Cet.ke-20.hal: 296. Jakarta: Nurani

${ }^{7}$ Depdikbud. 1990. Kamus Besar Bahasa Indonesia. Hal: 700. Jakarta: Balai Pustaka

${ }^{8}$ Halim M. 2009. Identifikasi Faktor-Faktor yang Berperan Terhadap Pencapaian Indeks Prestasi Kumulatif Mahasiswa Departemen Statistika IPB [Skripsi], Bogor: Jurusan Statistika FMIPA IPB

9 Sampoerno PD. 2002. Analisis kualitas Mahasiswa dalam Pencapaian Pendidikannya dengan Menggunakan Metode Partial Least Squares. Studi kasus: Mahasiswa jurusan Matematika FMIPA Universitas Jakarta [Tesis]. Bogor: Program Pasca Sarjana. IPB. 
tercapai apabila ada usaha-usaha yang serius dari pemerintah untuk meningkatkan mutu pendidikan nasional. Ketersediaan fasilitas pendidikan baik sarana maupun prasarana akan sangat menunjang dalam meningkatkan mutu pendidikan.

Prestasi yang dapat dicapai seseorang ditentukan oleh potensi dan motivasi yang dimiliki orang tersebut. Potensi adalah faktor kemampuan seseorang yang sudah dianggap tetap sedangkan motivasi adalah faktor yang dapat dikembangkan untuk mengoptimalkan prestasi seseorang. Oleh karena itu, dengan memaksimalkan motivasi maka prestasi yang dapat dicapai juga menjadi maksimal. Sedangkan betapapun tinggi atau besarnya potensi seseorang tetapi memiliki motivasi yang rendah maka prestasi yang akan dicapai juga akan rendah.

Menurut Sampoerno, kualitas seorang mahasiswa dapat dilihat dari prestasi yang dicapainya, potensi yang dimiliki, dan juga motivasi yang tinggi yang ada dalam diriny $\mathrm{a}^{10}$. Motivasi yang dimaksud adalah adanya keinginan yang besar untuk dapat meraih apa yang diinginkannya. Ada dua macam motivasi dapat mempengaruhi seseorang yaitu motivasi intrinksik dan motivasi ekstrinksik. Motivasi intrinksik adalah motivasi dari dalam diri orang itu sendiri, biasanya terdorong oleh rasa ingin tahu atau untuk mendapat kepuasan. Motivasi intrinksik seseorang tidak dapat dipengaruhi oleh apapun, karena hanya orang tersebutlah yang dapat mengubah motivasi dalam dirinya sendiri. Sedangkan motivasi ekstrinksik adalah motivasi dari luar diri seseorang yaitu berupa pengaruh pengaruh dari luar yang mengakibatkan orang tersebut berbuat sesuatu.

Munthe dalam Hidayati ${ }^{11}$, tingkat keberhasilan mahasiswa dalam proses pendidikan dipengaruhi banyak faktor, secara garis

${ }^{10}$ Sampoerno PD. 2002. Analisis kualitas Mahasiswa dalam Pencapaian Pendidikannya dengan Menggunakan Metode Partial Least Squares. Studi kasus: Mahasiswa jurusan Matematika FMIPA Universitas Jakarta [Tesis]. Bogor: Program Pasca Sarjana. IPB

${ }^{11}$ Hildayati, Marya. 2002. Penelusuran Faktor-faktor yang Mempengaruhi Prestasi Akademik Mahasiswa Semester I Universitas Ibnu Khaldun Bogor. Skripsi. Bogor: Jurusan statistika FMIPA IPB. 
besar faktor -faktor tersebut bisa dikelompokan menjadi 2, yaitu:

1. Faktor intelektual adalah kemampuan seseorang yang diperlihatkan melalui kecerdasan dan kepandaiannya dalam berpikir dan berbuat. Seperti bakat, kapasitas belajar, kecerdasan, dan hasil belajar yang telah dicapai dalam hal ini adalah jumlah nilai UAN SMU.

2.Faktor non -intelektual adalah segala kondisi dari dalam dan luar dirinya atau lingkungan sekitar, yang terkait dengan diri seorang dalam mempengaruhi kemampuan berpikir dan bertindak. Seperti masalah belajar, jenis kelamin, karir, sosial, emosional, jalur masuk IPB, keuangan, asal daerah, keluarga, pemakaian waktu luang, organisasi, sahabat, metode belajar serta lingkungan.

\section{Motivasi}

Motivasi berawal dari kata motif yang diartikan sebagai daya upaya yang mendorong seseorang untuk melakukan sesuatu. Motif dapat dikatakan sebagai daya penggerak dari dalam dan di dalam subyek untuk melakukan aktivitas-aktivitas tertentu demi mencapai suatu tujuan.

Istilah motivasi menunjuk kepada semua gejala yang terkandung dalam stimulasi tindakan kearah tujuan tertentu dimana sebelumnya tidak ada gerakan menuju kearah tujuan tersebut ${ }^{12}$.

Menurut ngalim purwanto, motivasi adalah suatu usaha yang disadari untuk mempengaruhi tingkah laku seseorang agar ia tergerak hatinya untuk berbuat sesuatu sehingga mencapai hasil atau tujuan yang diinginkanya ${ }^{13}$.

Crow and Crow berpendapat bahwa satu motif adalah suatu kecenderungan yang meliputi suatu derajad kesadaran terhadap tujuan. Ia dapat dipandang sebagai menandai suatu kondisi-kondisi atau kekuatan-kekuatan internal yang cenderung mendorong individu menuju dicapainya tujuan-tujuan tertentu.

\footnotetext{
${ }^{12}$ Oemar Hamalik, Psikologi Belajar (Bandung: Sinar Baru, 1992), hlm. 173

${ }^{13}$ Ngalim Purwanto. 2000. Psikologi Pendidikan. Bandung: PT Remaja Rosdakarya. hlm. 84
} 
Mc. Donald mengatakan bahwa, motivation is a energy change within the person characterized by affective arousal and anticipatory goal reactions. Motivasi adalah suatu perubahan energi di dalam pribadi seseorang yang ditandai dengan timbulnya afektif (perasaan) dan reaksi untuk mencapai tujuan ${ }^{14}$.

Sedangkan menurut Hamzah B. Uno, Motivasi adalah dorongan dasar yang menggerakkan seseorang bertingkah laku' Motivasi berarti dorongan atau daya penggerak untuk melakukan suatu kegiatan. Pendapat Suryabrata, motivasi merupakan keadaan pribadi seseorang yang mendorong individu untuk melakukan aktivitas-aktivitas tertentu untuk mencapai suatu tujuan. Motivasi dapat menentukan baik tidaknya dalam pencapaian tujuan ${ }^{16}$.

Berikut merupakan indikator motivasi menurut Wardiyati ${ }^{17}$ :

Tabel 1. Indikator Motivasi

\begin{tabular}{|c|l|l|}
\hline $\begin{array}{c}\text { Macam } \\
\text { Motivasi }\end{array}$ & \multicolumn{1}{|c|}{ Aspek } & \multicolumn{1}{c|}{ Indikator } \\
\hline a. Intrinsik & - Kebutuhan & - Keinginan belajar \\
& - Peningkatan pen- & - Senang mengikuti pelajaran \\
& getahuan & - Selalu menyelesaikan tugas \\
& - Cita-cita & - Mengembangkan bakat \\
& & - Meningkatkan pengetahuan \\
\hline
\end{tabular}

${ }^{14}$ Syaiful Bahri Djamarah. 2002. Psikologi Belajar. Jakarta: PT Rineka Cipta. hlm. 114

${ }^{15}$ Hamzah.B.Uno. 2009. Teori Motivasi dan Pengukurannya Analisis di Bidang Pendidikan. Hal.1. Jakarta:PT.Bumi Aksara

${ }^{16}$ Suryabrata, Sumadi. 2006. Psikologi Pendidikan. Jakarta: PT Raja Grafindo Persada.

${ }^{17}$ Wardiyati, Agustin. 2006. Hubungan antara Motivasi dengan Prestasi Belajar Bidang Studi Pendidikan Agama Islam. Skripsi. Jakarta: UIN Syarif Hidayatullah 


\begin{tabular}{|l|l|l|}
\hline b. Ekstrin- & - Sarana belajar & - Ingin mendapat perhatian \\
sik & - Lingkungan & - Ingin mendapat pujian \\
& sekitar & - Ingin mendapat penghar- \\
& gaan/hadiah \\
& & \begin{tabular}{l} 
dari guru atau sekolah \\
\hline
\end{tabular}
\end{tabular}

\section{Faktor Keluarga}

Menurut Ilsan dalam Kusumastuti ${ }^{18}$, keluarga merupakan lembaga pendidikan pertama dan utama dalam masyarakat, karena dalam keluargalah manusia dilahirkan, berkembang menjadi dewasa. Bentuk dan isi serta cara-cara pendidikan di dalam keluarga akan selalu mempengaruhi tumbuh dan berkembangnya watak, budi pekerti dan kepribadian tiap manusia.

Pendidikan yang diterima dalam keluarga inilah yang akan digunakan oleh anak sebagai dasar untuk mengikuti pendidikan selanjutnya di sekolah. Faktor orang tua sangat berpengaruh terhadap keberhasilan anak dalam belajar. Tinggi rendahnya pendidikan orang tua, besar kecilnya penghasilan, cukup kurang perhatian dan bimbingan orang tua, rukun atau tidaknya kedua orang tua, semuanya itu turut mempengaruhi percapaian hasil belajar.

\section{a) Pendidikan orang tua}

Partisipasi orang tua dalam pelaksanaan pendidikan secara sangat meyakinkan berpengaruh positif terhadap prestasi belajar murid dan menunjukkan semakin tinggi keterlibatan dan kepedulian terhadap masalah-masalah pendidikan di sekolah (Firdaus dalam Ilyas ${ }^{19}$.

${ }^{18}$ Kusumastuti, Tri Laswi. 2010. Hubungan antara Tingkat Pendidikan dan Penghasilan Orang Tua dengan Prestasi Belajar IPA Semester Satu Siswa Kelas Tujuh SMP Cinde Semarang Tahun Pelajaran 2010/2011.Penelitian Tindakan Kelas. Semarang. Diakses 23 April 2011 dalam situs web: http:/ / www.scribd.com/doc/55874141/Hubungan-Antara-Tingkat-Pendidikan-Dan-Penghasilan-Orang-Tua.

19 Ilyas. 2004. Pengaruh Komunikasi Orang Tua Terhadap Prestasi 
Pada umumnya pengetahuan orang tua sangat menentukan pendidikan keluarga (anak-anaknya). Tingkat pendidikan orang tua juga merupakan salah satu faktor yang berpengaruh terhadap proses dan prestasi belajar siswa (Suryabrata, 2002). Perhatian orang tua dengan penuh kasih sayang terhadap pendidikan anaknya, akan menumbuhkan aktivitas anak sebagai suatu potensi yang sangat berharga untuk menghadapi masa depan. Pengertian perhatian orang tua yang dimaksud di sini adalah tanggapan siswa atas perhatian orang tuanya terhadap pendidikan anaknya yaitu tanggapan tentang bagaimana cara orang tuanya memberikan bimbingan belajar di rumah, memperhatikan dan memenuhi kebutuhan-kebutuhan alat yang menunjang pelajaran, memberikan dorongan untuk belajar, memberikan pengawasan, dan memberikan pengarahan pentingnya belajar ${ }^{20}$.

Orang tua dengan tingkat pendidikan yang lebih tinggi juga memungkinkan untuk lebihpercaya diri pada kemampuan mereka dalam membantu anak-anak mereka belajar. Dengan tingkat keyakinan tersebut maka diperkirakan akan berpengaruh secara signifikan terhadap kemampuan akademis anak-anak.

Pendidikan orang tua erat kaitannya dengan bantuan orang tua dalam membantu proses belajar. Diharapkan semakin tinggi tingkat pendidikan orang tua semakin baik pula prestasi belajar anaknya. Meskipun demikian, belum tentu seseorang yang tingkat pendidikannya rendah maka tingkat pengetahuannya juga rendah. Oleh karena itu, perlu dipertimbangkan bahwa faktor tingkat pendidikan juga menentukan mudah tidaknya seseorang menyerap dan memahami informasi yang diperoleh (Apriadji dalam Faridi ${ }^{21}$ ).

Diharapkan semakin tinggi tingkat pendidikan orang tua se-

Belajar Siswa Pada MTsN Model Makassar. Tesis. Makassar: Universitas Hasanuddin

${ }^{20}$ Suryabrata, Sumadi. 2006. Psikologi Pendidikan. Jakarta: PT Raja Grafindo Persada.

${ }^{21}$ Faridi, Achmad. 2002. Hubungan sarapan pagi dengan kadar glukosa darah dan konsentrasi belajar pada siswa SD. Skripsi. Bogor: GMSK Faperta IPB 
makin baik pula prestasibelajar anaknya. Orang tua yang kurang memperhatikan pendidikan anaknya, misalnya mereka acuh tak acuh terhadap belajar anaknya, sama sekali tidak memperhatikan kepentingan dan kebutuhan anaknya dalam belajar, tidak mengatur waktu belajar, tidak menyediakan atau melengkapi alat belajar, tidak mau tahu bagaimana kemajuan belajar anaknya, tidak memahami kesulitan yang dialami dalam belajar dan lain-lain yang dapat menyebabkan anak kurang berhasil dalam belajar menurut pendapat Slameto ${ }^{22}$.

Ada kemungkinan orang tua yang berpendidikan tinggi mengasuh anak rendah ada kemungkinan mengasuh dengan pola asuh tertutup bahkan bebas. Pandangan Lidia bahwa alam hal pendidikan anak, orang tua yang berpendidikan tinggi tidak hanya menekan anak untuk mendapat prestasi yang baik tetapi lebih memberi arahan pada anak agar dapat mencapai prestasi yang baik ${ }^{23}$.

\section{b) Keadaan ekonomi keluarga}

Faktor keluarga lebih banyak mempengaruhi kegiatan belajar mahasiswa yaitu orang tua dan keluarga mahasiswa itu sendiri. Menurut Muhibbin Syah, sifat-sifat orang tua, praktik pengelolaan keuangan, ketegangan keluarga, dan demografi keluarga, semuanya dapat memberikan dampak baik maupun buruk terhadap kegiatan belajar dan hasil yang dicapai oleh mahasiswa ${ }^{24}$.

Lingkungan pendidikan yang mula-mula tetapi terpenting adalah keluarga. Pada masyarakat yang masih sederhana dengan struktur sosial yang belum kompleks, cakrawala anak sebagian besar masih terbatas pada keluarga. Keluarga menurut Tirtarahardja dan La Sulo adalah pengelompokan primer yang terdiri dari se-

22 Slameto. 1995. Belajar dan Faktor-faktor yang Mempengaruhinya. Jakarta: PT Rineka Cipta

${ }^{23}$ Lidia, Susi. 2008. Pngaruh Pola Asuh Orang Tua dan Disiplin Belajar Terhadap Prestasi Belajar Ekonomi Siswa Kelas VIII SMP Negeri 5 Brebes Tahun Ajaran 2007/2008. Skripsi. Surakarta: UMS

${ }^{24}$ Muhibbin Syah. 2008. Psikologi Pendidikan dengan Pendekatan Baru. Hal.138. Bandung:Remaja Rosdakarya 
jumlah kecil orang karena hubungan semenda (hubungan menurut garis ibu) dan sedarah. Keluarga itu dapat berbentuk keluarga inti (nucleus family: ayah, ibu dan anak), ataupun keluarga yang diperluas (disamping inti, ada orang lain: kakek/nenek, adik/ipar, pembantu, dll $)^{25}$.

Lingkungan keluarga merupakan lingkungan pertama yang mempunyai pengaruh kuat kepada individu dibandingkan dengan lingkungan sekunder yang ikatannya agak longgar. Faktor-faktor keluarga yang berpengaruh terhadap prestasi belajar menurut Slameto yakni, cara orang tua mendidik, suasana rumah, keadaan ekonomi keluarga, perhatian orang tua, dan relasi antar anggota keluarga diduga memiliki pengaruh terhadap prestasi belajar mahasiswa ${ }^{26}$. Uwaifo (2008) dan Syahadatina (2011) menunjukkan bahwa terdapat pengaruh signifikan antara lingkungan keluarga dan prestasi belajar siswa. Sebaliknya, penelitian yang dilakukan oleh Iswanti (2002) dan Tanwil dan Suryansari (2008) tidak menemukan adanya pengaruh antara lingkungan keluarga dan prestasi belajar, begitu juga dengan penelitian yang dilakukan oleh Sagita Adjani dan Helmy Adam (2008), mendapati bahwa faktor lingkungan keluarga tidak berpengaruh terhadap prestasi belajar mahasiswa dalam mata kuliah Pengantar Akuntansi ${ }^{27}$.

\section{Lingkungan Kampus}

Lingkungan kampus berperan membantu keluarga dalam pendidikan anak-anak atau peserta didik. Proses pembelajaran di sekolah bertujuan untuk mengantarkan pembelajar memiliki kompetensi dalam aspek kognitif (pengetahuan); afektif (sikap dan nilai) dan psikomotor (ketrampilan) serta bertujuan untuk menciptakan

${ }^{25}$ Umar Tirtarahardja \& La Sulo. 2005. Pengantar Pendidikan. Jakarta: PT Rineka Cipta. hlm.168

${ }^{26}$ Slameto. 2003. Belajar dan Faktor - Faktor yang mempengeruhinya. hal:61. Jakarta: Rineka Cipta

${ }^{27}$ Sagita Adjani dan Helmy Adam. 2008. Faktor-faktor yang Mempengaruhi Prestasi Belajar Mahasiswa Pada Mata Kuliah Pengantar Akuntansi. Skripsi. Universitas Brawijaya 
tenaga kerja nantinya ${ }^{28}$.

Baik buruknya kondisi lingkungan fisik juga akan berpengaruh terhadap prestasi belajar peserta didik kondisi lingkungan yang gaduh, kotor, panas, belajarnya menjadi kurang efektif. Sebaliknya kondisi yang tenang dan bersih, sejuk, segar akan membantu meningkatkan konsentrasi dalam belajar.

Lingkungan non fisik memiliki peran yang besar juga dalam pengaruhnya terhadap kondisi belajar terutama pengaturan lingkungan belajar, penampilan, sikap pendidik, hubungan yang harmonis antara pendidik dan peserta didik dan antara sesama peserta didik itu sendiri, serta organisasi dan bahan pembelajaran secara tepat, sesuai dengan kemampuan dan perkembangan peserta didik. Kemudian dalam Kurikulum Tingkat Satuan Pendidikan (KTSP) lebih berorientasi kepada proses bukan berorientasi kepada materi. (Yamin, 2007)

Menurut Soedomo, bahwa semakin menyenangkan tata lingkungan fisik, akan memberi dampak positif bagi proses belajar $(\mathrm{Mu}-$ lyasa, 2005).

\section{HIPOTESIS PENELITIAN}

Berdasarkan teori yang ada dan penelitian terdahulu dapat dirumuskan hipotesis dalam penelitian ini yaitu:

H1: Ada pengaruh yang signifikan antara motivasi dengan prestasi akademik mahasiswa

H2: Ada pengaruh yang signifikan antara faktor keluarga dengan prestasi akademik mahasiswa

H3: Ada pengaruh yang signifikan antara lingkungan kampus dengan prestasi akademik mahasiswa

H4: Ada pengaruh yang signifikan antara aktif organisasi dengan prestasi akademik mahasiswa

${ }^{28}$ Udiyono. 2011. Pengaruh Motivasi Orangtua, Kondisi Lingkungan Dan Disiplin Belajar Terhadap Prestasi Akademik Mahasiswa. Magistra No. 75 Th. XXIII Maret 2011.ISSN 0215-9511 


\section{METODE PENELITIAN}

\section{Jenis Penelitian}

Jenis penelitian yang digunakan adalah penelitian kuantitatif. Metode kuantitatif dinamakan metode tradisional, karena metode ini sudah cukup lama digunakan sehingga sudah mentradisi sebagai metode untuk penelitian. Metode ini disebut sebagai metode positivistik karena berlandaskan pada filsafat positivisme. Metode ini sebagai metode ilmiah karena telah memenuhi kaidah-kaidah ilmiah yaitu konkrit, obyektif, terukur, rasional, dan sistematis. Metode ini disebut metode kuantitatif karena data penelitian berupa angka-angka dan analisis menggunakan statistik menurut Sugiyono ${ }^{29}$.

\section{Populasi}

Dalam penelitian kuantitatif, populasi diartikan sebagai wilayah generalisasi yang terdiri atas: obyek/subjek yang mempunyai kualitas dan karakteristik tertentu yang ditetapkan oleh peneliti untuk dipelajari dan kemudian ditarik kesimpulannya ${ }^{30}$. Sedangkan Arikunto mengartikan populasi adalah keseluruhan subjek penelitian. Apabila seseorang ingin meneliti semua elemen yang ada dalam wilayah penelitian, maka juga disebut studi populasi atau studi sensus ${ }^{31}$.

Populasi dalam penelitian ini adalah seluruh mahasiswa Fakultas Ilmu Tarbiyah dan Keguruan (FITK) semester GASAL 2013/2014 yang berada di semester 3 ke atas, sedangkan mahasiswa yang berada di semester 1 tidak dilibatkan dalam penelitian ini karena belum mempunyai nilai IPK (Indeks Prestasi Kumulatif).

${ }^{29}$ Sugiyono. 2010. Metode Penelitian Kuantitatif, Kualitatif dan R \& D. Bandung: PT. Alfabeta. Hal: 7

${ }^{30}$ Sugiyono. 2010. Metode Penelitian Kuantitatif, Kualitatif dan R \& D. Bandung: PT. Alfabeta. Hal: 215

31 Arikunto, Suharsimi. 2006. Metode Penelitian Suatu Pendekatan Praktik. Jakarta: PT. Rineka Cipta.Hal:130 


\section{Sampel}

Sampel menurut Sugiyono adalah sebagian dari jumlah dan karakteristik yang dimiliki oleh populasi ${ }^{32}$. Arikunto menyatakan bahwa apabila subjek penelitian kurang dari seratus, lebih baik diambil semua, apabila jumlahnya cukup besar dapat diambil sebanyak $10 \%-15 \%$ atau $20 \%-25 \%$ atau lebih ${ }^{33}$. Sampel yang diambil dalam penelitian ini adalah 265 .

\section{Instrumen Pengumpulan Data}

Instrumen pengumpulan data dalam penelitian ini adalah menggunakan angket. Angket (questionnaire) adalah daftar pertanyaan yang diberikan kepada orang lain bersedia memberikan respons (responden) sesuai dengan permintaan pengguna ${ }^{34}$.

Angket untuk menghimpun data dengan cara mengajukan pernyataan yang disusun dengan sistematis, kemudian disebarkan kepada responden dengan cara memberikan langsung kepada responden dan melalui perantara. Instrumen penelitian ini dipergunakan untuk menetapkan jawaban-jawaban atas sejumlah pertanyaan melalui formulir yang akan diisi oleh responden sendiri. Isi angket berupa sekelompok pernyataan tertulis (tercetak) dengan sistem tertentu yang perlu dijawab dengan tertulis pula, sehingga hubungan antara peneliti dan respondennya menjadi tidak langsung. Teknik kuesioner seringkali sangat tepat sebagai suatu instrumen metode penelitian untuk mendapatkan data yang cukup luas yang dihimpun dari populasi yang besar, heterogen, dan tempatnya sporadis ${ }^{35}$.

32 Sugiyono. 2010. Metode Penelitian Kuantitatif, Kualitatif dan R \& D. Bandung: PT. Alfabeta. Hal: 56

33 Arikunto, Suharsimi. 2006. Metode Penelitian Suatu Pendekatan Praktik. Jakarta: PT. Rineka Cipta.Hal:134

34 Riduwan. 2010. Skala Pengukuran Variabel-Variabel Penelitian. Bandung: Alfabeta.Hal:25-26

${ }^{35}$ Sutama. 2010. Metode Penelitian Pendidikan Kuantitatif, Kualitatif, PTK, R\&D. Surakarta: Fairuz Media.hal:94 


\section{Metode Analisis Data}

Analisis data dalam penelitian ini menggunakan regresi berganda. Analisis regresi berganda yaitu suatu metode analisis yang digunakan untuk mengetahui seberapa besar pengaruh variabel pada variabel yang lain. Terdapat satu variabel dependen dan lebih dari satu variabel independen ${ }^{36}$.

Persamaan regresi linear berganda sebagai berikut:

$$
Y^{\prime}=a+b_{1} X_{1}+b_{2} X_{2}+b_{3} X_{3}+b_{4} X_{4}+b_{5} X_{5}
$$

Keterangan:

$\mathrm{Y}^{\prime}=$ Variabel dependen (nilai yang diprediksikan yaitu IPK)

$\mathrm{X}_{1}=$ Motivasi

$X_{2}=$ Faktor Keluarga

$\mathrm{X}_{3}=$ Lingkungan Kampus

$\mathrm{X}_{4}=$ Aktif Berorganisasi

$\mathrm{a}=$ Konstanta (nilai $Y^{\prime}$ apabila $X_{1}, X_{2} \ldots . . X_{n}=0$ )

$\mathrm{b}=$ Koefisien regresi (nilai peningkatan ataupun penurunan)

\section{PEMBAHASAN HASIL}

\section{KARAKTERISTIK RESPONDEN}

Adapun rincian dari karakteristik responden dalam penelitian ini adalah sebagai berikut:

\section{a. Jurusan}

Jurusan responden dalam penelitian ini adalah seluruh jurusan yang ada di FITK berjumlah 9 terdiri dari PAI (Pendidikan Agama Islam), PBA (Pendidikan Bahasa Arab), KI (Kependidikan Islam), Tadris Bahasa Inggris, Tadris Biologi, Tadris Fisika, Tadris Kimia, Tadris Matematika dan PGMI (Pendidikan Guru Madrasah Ibtidaiyah). Distribusi jurusan dapat dilihat dalam grafik 1 berikut:

${ }^{36}$ Santoso dan Tjiptono. 2004. Riset Pemasaran Konsep dan Aplikasi dengan SPSS.PT Elex Media Komputindo, Jakarta 


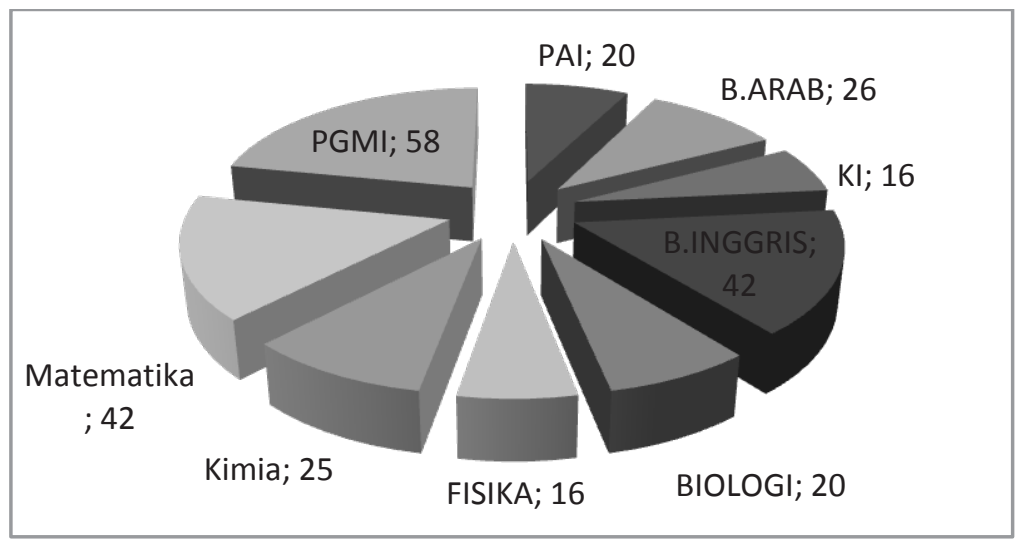

\section{Grafik 1: Jurusan Responden}

Berdasarkan grafik 1 di atas distribusi jurusan responden adalah jurusan PAI berjumlah 7,5\%, jurusan PBA berjumlah 9,8\%, jurusan KI berjumlah 6,4\%, jurusan Bahasa Inggris berjumlah 15,8\%, jurusan Tadris Biologi berjumlah 7,5\%, jurusan Tadris Fisika berjumlah 6\%, jurusan Tadris Kimia berjumlah 9,4\%, jurusan Tadris Matematika berjumlah 15,8\%, dan jurusan PGMI berjumlah 21,8\%.

\section{b. IPK}

Prestasi akademik responden dalam penelitian ini diperoleh dari nilai IPK (Indeks Prestasi Kumulatif) mahasiswa semester GENAP 2012/2013. Adapun distribusi IPK mahasiswa FITK dapat dilihat dalam tabel 1 berikut:

Tabel 1: Prestasi Akademik Responden (IPK)

\begin{tabular}{|c|c|c|c|}
\hline Rata-rata & Standar Deviasi & Nilai Minimal & Nilai Maksimal \\
\hline 3,45 & 0,28 & 1,87 & 4,00 \\
\hline
\end{tabular}

Dalam tabel 1 di atas dapat diketahui bahwa rata-rata nilai IPK mahasiswa FITK dalam penelitian ini adalah 3,45, sedangkan nilai IPK mahasiswa FITK tertinggi adalah 4,00 (cumlaude) dan nilai IPK yang terendah adalah 1,87.

\section{c. Jenis Kelamin}

Berdasarkan grafik 2 di bawah ini dapat di ketahui bahwa 
jumlah responden berdasarkan jenis kelamin yang paling banyak adalah perempuan sejumlah $74 \%$ dan sisanya $26 \%$ laki-laki. Distribusi jenis kelamin ini sesuai dengan kenyataan yang ada di FITK bahwa mahasiswa perempuan lebih banyak dibandingkan mahasiswa yang laki-laki.

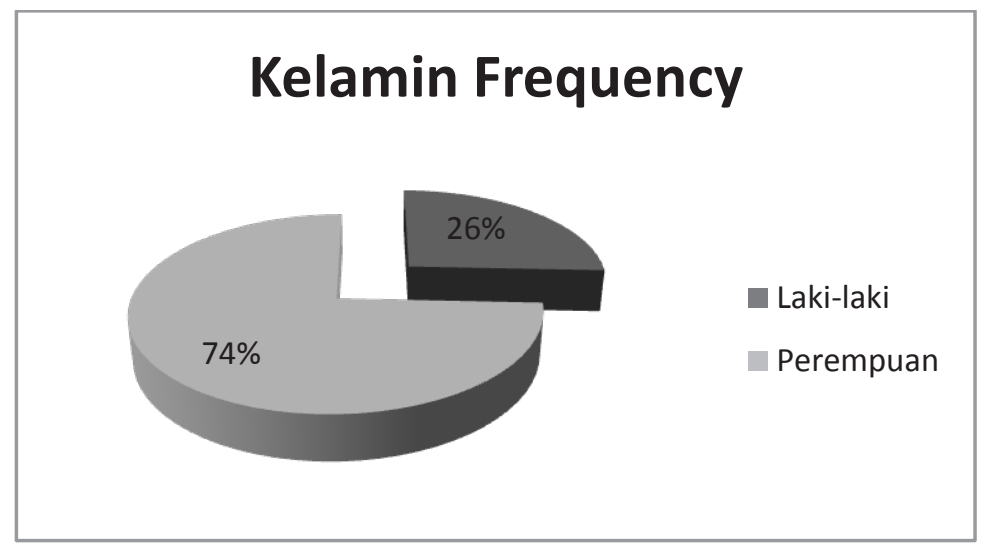

\section{Grafik 2: Jenis Kelamin}

\section{d. Tempat Tinggal}

Tempat tinggal responden dalam penelitian ini terdapat 4 pilihan jawaban yaitu: dengan orangtua/wali, asrama, kos dan lainnya. Distribusi tempat tinggal responden dapat dilihat dalam grafik 3 berikut:

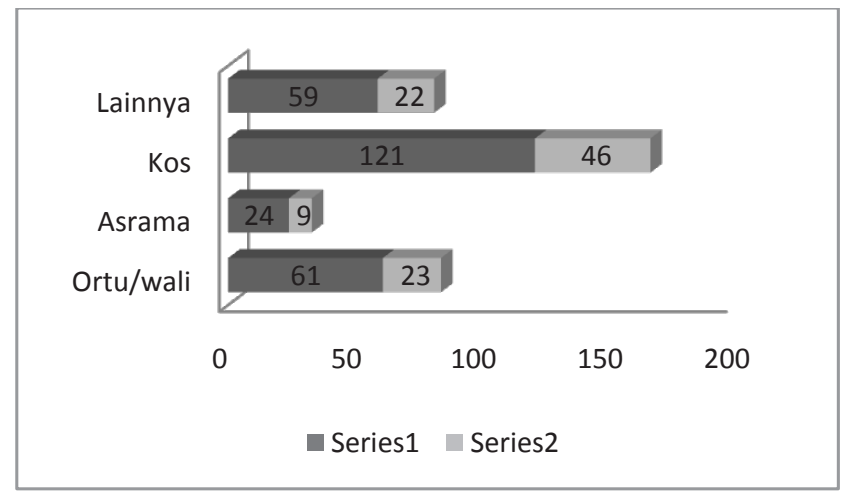

Grafik 3: Tempat Tinggal Responden

Dari grafik 3 di atas diketahui bahwa mahasiswa FITK 
paling banyak tinggal di kos sejumlah $46 \%$, diikuti $23 \%$ tinggal bersama orang tuanya atau walinya, kemudian $22 \%$ tinggal pada pilihan lainnya diantaranya pondok pesantren, rumah kontrakan, dan lainnya, kemudian hanya 9\% yang tinggal di asrama/ma'had walisongo.

\section{e.Waktu Tempuh dari Tempat Tinggal ke Kampus}

Pilihan jawaban responden tentang waktu tempuh dari tempat tinggal mahasiswa ke kampusFITK dalam penelitian ini terdiri dari 5 pilihan, yaitu < 10 menit, 10 - 20 menit, 21 - 30 menit, 31 - 40 menit dan $>41$ menit. Distribusi waktu tempuh dari tempat tinggal mahasiswa ke kampus FITK dapat dilihat dalam grafik berikut:

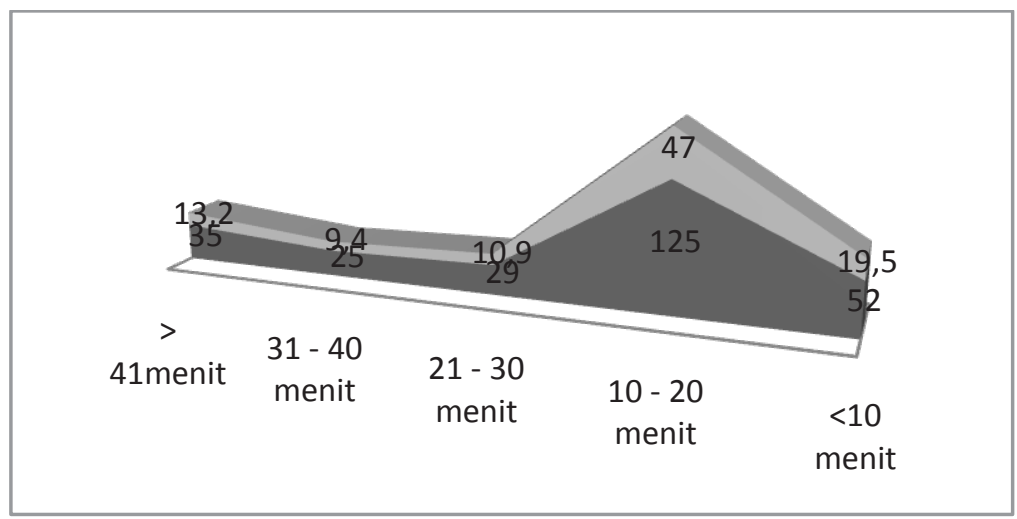

\section{Grafik 4: Waktu Tempuh ke Kampus}

Berdasarkan grafik 4 di atas dapat diketahui bahwa mahasiswa FITK membutuhkan waktu untuk sampai ke kampus dari tempat tinggalnya paling banyak $47 \%$ hanya 10 - 20 menit, mahasiswa paling cepat sampai ke kampus membutuhkan waktu $<10$ menit sejumlah 19,5\%, kemudian paling lama waktu tempuh mahasiswa menuju ke kampus yaitu $>41$ menit sejumlah $13,2 \%$,selanjutnya sejumlah $10,9 \%$ mahasiswa membutuhkan waktu sampai ke kampus yaitu 21 - 30 menit, dan hanya 9,4\% mahasiswa FITK membutuhkan waktu sampai ke kampus 31 40 menit.

\section{f. Organisasi/ UKM}


Organisasi dalam penelitian ini maksudnya adalah organisasi-organisasi yang diikuti oleh mahasiswa FITK baik yang ada di dalam Institusi maupun di luar institusi. Organisasi yang ada di IAIN Walisongo Semarang diantaranya adalah HMJ (Himpunan Mahasiswa Jurusan), UKM BITA, LSB (Lembaga Studi Bahasa), Koperasi Mahasiswa (KOPMA), Walisongo English Club (WEC), WSC (Walisongo Sport Club),HIMABIO, HIMMAKI, HIMMATIKA, Tarbiyah Sport Club, Racana Walisongo, dll. Sedangkan organisasi/UKM yang diikuti mahasiswa FITK di luar IAIN diantaranya adalah Himpunan Mahasiswa JABAR, Himpunan Mahasiswa Purwakarta, PC IPPNU Kab. Demak, dll.

Pilihan jawaban responden tentang organisasi dalam penelitian ini terdiri dari dua pilihan yaitu Ya dan Tidak. Adapun distribusi organisasi/UKM yang diikuti mahasiswa FITK dapat dilihat dalam grafik 5 berikut:

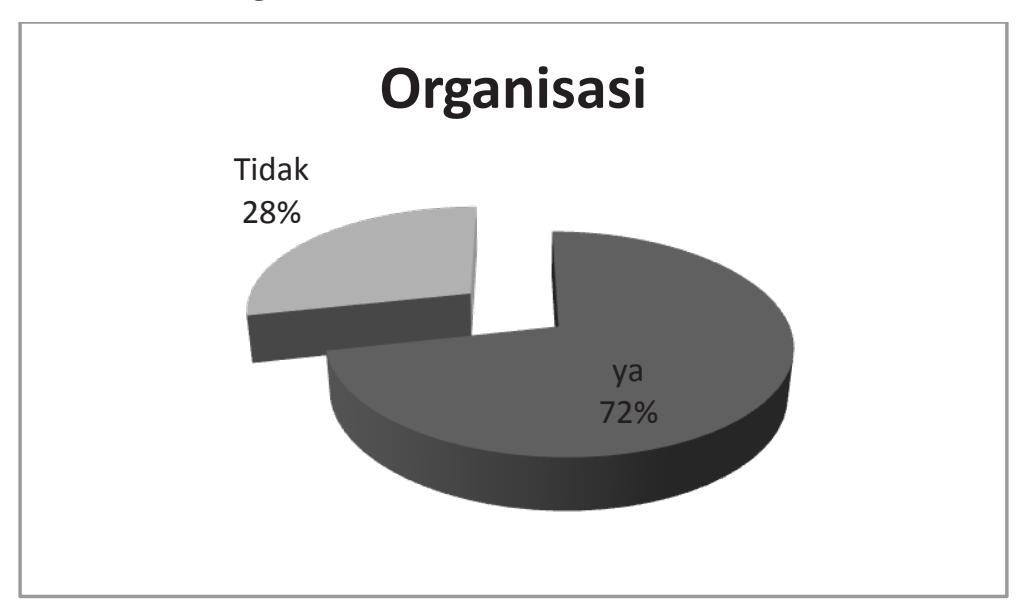

\section{Grafik 5: Organisasi/ UKM}

Berdasarkan grafik 5 di atas dapat diketahui bahwa sebagian besar jumlah mahasiswa FITK yaitu $72 \%$ mengikuti organisasi baik di dalam IAIN maupun di luar IAIN, sedangkan mahasiswa FITK yang tidak mengikuti organisasi/UKM hanya $28 \%$. 


\section{ANALISIS DATA}

\section{a. Uji Instrumen}

\section{Uji Validitas}

Uji validitas digunakan untuk mengukur sah atau valid tidaknya suatu kuesioner. Suatu kuesioner dikatakan valid jika pertanyaan pada kuesioner mampu untuk mengungkapkan sesuatu yang akan diukur oleh kuesioner tersebut. Dalam penelitian ini untuk mengukur validitas digunakan Coeficient correlation pearson yaitu dengan menghitung korelasi antara score masing-masing butir pertanyaan dengan total score, Imam (2005). Variabel motivasi terdiri atas 15 item pernyataan, variabel faktor keluarga terdiri dari 4 item pernyataan, variabel lingkungan kampus terdiri dari 13 item pernyataan, dan variabel aktif organisasi terdiri dari 2 item pernyataan.

Hasil pengujian validitas dianalisis dengan menggunakan bantuan program SPSS 18. Hasil uji validitas menunjukkan bahwa semua item pernyataan dalam penelitian ini adalah valid.

\section{Uji Reliabilitas}

Uji Reliabilitas digunakan untuk mengukur suatu kuesioner yang merupakan indikator dari variabel atau konstruk. Suatu kuesioner dikatakan reliabel atau handal jika jawaban seseorang terhadap pernyataan adalah konsisten atau stabil dari waktu ke waktu (Imam, 2001). Pengukuran dengan one shot atau pengukuran sekali saja digunakan dalam penelitian ini. Nunally dalam Imam, suatu konstruk atau variabel dikatakan reliabel, jika memberikan nilai cronbach alpha > 0,60 (Nunally, 1969 dalam Imam, 2005).

Tabel 2: Hasil Uji Reliabilitas

\begin{tabular}{|c|c|}
\hline Variabel & Cronbach's Alpha \\
\hline Motivasi & 0,756 \\
\hline Faktor Keluarga & 0,747 \\
\hline Lingkungan kampus & 0,794 \\
\hline Aktif Organisasi & 0,689 \\
\hline
\end{tabular}


Dari tabel 2 diatas menunjukkan nilai cronbach's alpha instrumen variabel motivasi sebesar 0,756, variabel faktor keluarga sebesar 0,747, variabel lingkungan kampus sebesar 0,794 dan instrumen variabel aktif organisasi sebesar 0,720. Artinya instrumen variabel motivasi, factor keluarga, lingkungan kampus dan aktif organisasi adalah handal atau reliabel untuk digunakan dalam pengolahan data.

\section{b. Analisis Regresi Berganda}

Regresi linier berganda merupakan perluasan dari regresi linier sederhana dengan dua atau lebih variabel bebas yang digunakan sebagai predictor dan satu variabel tergantung yang diprediksi ${ }^{37}$. Berdasarkan perhitungan regresi berganda variabel motivasi, faktor keluarga, lingkungan kampus dan aktif organisasi terhadap prestasi akademik dengan menggunakan SPSS 18 diperoleh hasil sebagai berikut:

\section{Model Summary}

Bagian ringkasan model (model summary) menunjukkan besarnya koefisien determinasi ( $R$ square) yang berfungsi untuk mengetahui besarnya variabilitas variabel tergantung prestasi akademik yang dapat diterangkan oleh variabel bebas.

\begin{tabular}{|c|c|c|c|c|c|}
\hline \multicolumn{7}{|c|}{ Tabel 3: Ringkasan Model } \\
\hline Model & $\mathrm{R}$ & $\mathrm{R}^{2}$ & $\begin{array}{c}\mathrm{R}^{2} \\
\text { Diselaraskan }\end{array}$ & $\begin{array}{c}\text { Estimasi } \\
\text { Std. Error }\end{array}$ & Durbin-Watson \\
\hline 1 &, $979 \mathrm{a}$ &, 958 &, 958 &, 04944037 & 2,089 \\
\hline $\begin{array}{c}\text { a. Prediktor: (Constant), lpm_lx4 (aktif organisasi), } \\
\text { lpm_lx1 (motivasi), lpm_lx2 (factor keluarga), lpm_ } \\
\text { lx3 (lingkungan kampus) }\end{array}$ & \\
\hline
\end{tabular}

37 Sarwono,jonathan \& Budiono,herlina.2012. Statistik Terapan: Aplikasi untuk Riset Skripsi, Tesis dan Disertasi. Hal:189 Jakarta: PT.Elex Media Komputindo 


\begin{tabular}{|c|c|c|c|c|c|}
\hline \multicolumn{7}{|c|}{ Tabel 3: Ringkasan Model } \\
\hline Model & $\mathrm{R}$ & $\mathrm{R}^{2}$ & $\begin{array}{c}\mathrm{R}^{2} \\
\text { Diselaraskan }\end{array}$ & $\begin{array}{c}\text { Estimasi } \\
\text { Std. Error }\end{array}$ & Durbin-Watson \\
\hline 1 &, $979^{\mathrm{a}}$ &, 958 &, 958 &, 04944037 & 2,089 \\
\hline \multicolumn{7}{|c|}{$\begin{array}{c}\text { b. Variabel Dependen: lpm_ly } \\
\text { (prestasi akademik) }\end{array}$} & i akademik) & \\
\hline
\end{tabular}

Dalam tabel 3 di atas diperoleh nilai $\mathrm{R}$ square Adjusted $\mathrm{R}$ Square sebesar 0,958 atau 95,8\%. Angka tersebut berarti bahwa $95,8 \%$ prestasi akademik yang terjadi dapat dijelaskan oleh variabel bebas: motivasi, faktor keluarga, lingkungan kampus, dan aktif organisasi. Sedangkan sisanya 4,2\% dijelaskan oleh faktor lain di luar model regresi ini.

Nilai Durbin - Watson pada tabel di atas sebesar 2, 089. Nilai ini mempunyai makna tidak terjadi otokorelasi dalam model regresi ini. Ketentuannya ialah akan terjadi otokorelasi jika nilai Durbin - Watson: $1<\mathrm{DW}>3^{38}$.

\section{Anova}

Bagian ini menunjukkan besarnya angka probabilitas atau signifikansi pada perhitungan Anova yang akan digunakan untuk uji kelayakan model regresi dengan ketentuan angka probabilitas yang baik untuk digunakan sebagai model regresi ialah harus lebih kecil dari 0,05.

\begin{tabular}{|c|c|c|c|c|c|c|}
\hline \multicolumn{7}{|c|}{ Tabel 4: ANOVA } \\
\hline \multicolumn{2}{|c|}{ Model } & Total $^{2}$ & $\mathrm{df}$ & Rerata $^{2}$ & F & Sig. \\
\hline \multirow[t]{3}{*}{1} & Regresi & 14,566 & 4 & 3,642 & $14,90 \mathrm{E} 3$ &, $000^{\mathrm{a}}$ \\
\hline & Residu & ,636 & 260 &, 002 & & \\
\hline & Total & 15,202 & 264 & & & \\
\hline & $\begin{array}{l}\text { Predikto } \\
\qquad 1 \mathrm{x}\end{array}$ & $\begin{array}{l}\text { konstan } \\
\text { pm_lx2, }\end{array}$ & $1 \times 3$ & $=\mathrm{lpm}_{-}$ & & \\
\hline
\end{tabular}

${ }^{38}$ Sarwono,jonathan \& Budiono,herlina.2012. op.cit. hal: 179 


\begin{tabular}{|c|c|c|c|c|c|c|}
\hline \multicolumn{7}{|c|}{${\text { Tabel 4: } \text { ANOVA }^{\mathrm{b}}}^{2}$} \\
\hline Model & Total $^{2}$ & df & Rerata $^{2}$ & F & Sig. \\
\hline \multirow{2}{*}{1} & Regresi & 14,566 & 4 & 3,642 & $14,90 \mathrm{E} 3$ &, $000^{\mathrm{a}}$ \\
\cline { 2 - 7 } & Residu &, 636 & 260 &, 002 & & \\
\cline { 2 - 7 } & Total & 15,202 & 264 & & & \\
\hline \multicolumn{2}{|c|}{$\begin{array}{l}\text { b. Variabel Dependen: } \\
\text { lpm_ly }\end{array}$} & & & & \\
\hline
\end{tabular}

Uji Anova menghasilkan angka F sebesar 14,90 ×103 dengan tingkat signifikansi (angka probabilitas) sebesar 0,000. Karena angka probabilitas 0,000 < 0,05 maka model regresi ini sudah layak untuk digunakan dalam memprediksi prestasi akademik mahasiswa.

\section{Uji hipotesis secara simultan (uji F)}

Uji hipotesis secara simultan (uji F) bertujuan untuk mengetahui apakah variabel bebas $(X)$ secara bersama berpengaruh terhadap variabel terikat $(\mathrm{Y})$. Apabila $\mathrm{F}$ hitung $>$ F tabel maka secara simultan terdapat pengaruh yang signifikan antara variabel independen $(X)$ terhadap variabel dependen $(Y)$. Dari hasil perhitungan dengan SPSS diperoleh hasil uji $\mathrm{F}$ yaitu $\mathrm{F}$ hitung sebesar $14,90 \times 10^{3}$ serta F tabel sebesar 2,63. Karena Fhitung $>$ Ftabel $\left(14,90 \times 10^{3}>2,63\right)$ dengan signifikan 0,000 $<0,05$. Hal ini berarti terdapat pengaruh positif dan signifikan antara motivasi, faktor keluarga, lingkungan kampus, dan aktif organisasi secara simultan (bersama-sama) terhadap prestasi akademik mahasiswa FITK. 
Koefisien Regresi

Tabel 5: Hasil Koefisien Regresi Berganda

\begin{tabular}{|c|c|c|c|c|c|}
\hline \multirow[t]{2}{*}{ Model } & \multicolumn{2}{|c|}{$\begin{array}{l}\text { Unstandardized } \\
\text { Coefficients }\end{array}$} & \multirow{2}{*}{$\begin{array}{c}\text { Standardized } \\
\text { Coefficients } \\
\text { Beta } \\
\end{array}$} & \multirow[t]{2}{*}{$\mathrm{t}$} & \multirow[t]{2}{*}{ sig } \\
\hline & B & Std. Error & & & \\
\hline $\begin{array}{l}\text { (Con- } \\
\text { stant) }\end{array}$ & $-1,786$ & ,052 & & $-34,621$ & ,000 \\
\hline lpm_1x1 & 452 & ,008 & 1,059 & 55,654 & ,000 \\
\hline lpm_1x2 & -066 & ,006 & -155 & $-11,355$ & ,000 \\
\hline lpm_1x3 &,- 024 & ,009 &,- 050 & $-2,626$ & ,009 \\
\hline lpm_1x4 &,- 048 & ,006 &,- 108 & $-8,127$ & , 000 \\
\hline
\end{tabular}

a. Dependent Variable:

lpm_ly

Hasil analisis regresi berganda dengan SPSS 18,00 diperoleh koefisien (bX1) sebesar 0,452, koefisien (bX2) sebesar $-0,066$, koefisien (bX3) sebesar -0,024, dan koefisien (bX4) sebesar $-0,048$, sedangkan bilangan konstanta (a) sebesar $-1,786$. Berdasarkan koefisien tersebut dapat disusun persamaan garis regresi berganda sebagai berikut:

$$
Y=-1,786+0,452 X 1+(-0,066 X 2)+(-0,024 X 3)+(-0,48 X 4)
$$

\section{Uji hipotesis secara parsial (uji t)}

Uji hipotesis secara parsial (uji t) bertujuan untuk mengetahui apakah masing-masing variabel bebas berpengaruh terhadap variabel terikat. Apabila $t$ hitung $>t$ tabel maka secara parsial terdapat pengaruh yang signifikan antara variabel independen $(X)$ terhadap variabel dependen $(Y)$. Pengujian hipotesis secara parsial dapat dirincikan sebagai berikut:

a. Hipotesis pertama menyatakan bahwa ada pengaruh signifikan antara motivasi terhadap prestasi akademik mahasiswa FITK. Hipotesis ini diuji dengan membandingkan nilai $\mathrm{t}$ hitung dengan nilai $\mathrm{t}$ tabel. Dengan taraf signifikan yang digunakan sebesar 5\% dengan derajat kebebasan, df 
$=(\mathrm{n}-\mathrm{k}-1)=265-4-1=260$, di mana $\mathrm{k}$ merupakan variabel bebas, maka nilai t tabel $=1,96$. Berdasarkan tabel 5, nilai t hitung dari variabel motivasi adalah sebesar55,654. Karena $\mathrm{t}$ hitung $>\mathrm{t}$ tabel $(55,654>1,96)$ dengan nilai signifikansi sebesar 0,000 <0,05, berarti motivasi berpengaruh signifikan secara parsial terhadap prestasi akademik mahasiswa FITK. Dengan demikian hipotesis penelitian pertama diterima. Hal ini sesuai dengan pendapat Sardiman A.M.bahwa dalam kegiatan belajar, motivasi dapat dikatakan sebagai keseluruhan daya penggerak di dalam diri siswa yang menimbulkan kegiatan belajar, yang menjamin kelangsungan dari kegiatan belajar dan yang memberikan arah pada kegiatan belajar, sehingga tujuan yang dikehendaki oleh subjek belajar itu dapat tercapai ${ }^{39}$. Hasil penelitian ini didukung oleh penelitian yang dilakukan oleh (oki dkk tahun 2012, irfan affandi tahun 2011 dan juga sri minatun tahun 2011). Demikian juga dengan hasil penelitian yang telah dilakukan oleh udiyono tahun 2011 bahwa motivasi berpengaruh positif terhadap prestasi akademik.

b. Hipotesis kedua menyatakan bahwa faktor keluarga berpengaruh signifikan terhadap prestasi akademik mahasiswa FITK. Dengan nilai t hitung sebesar 11,355 ( $>\mathrm{t}$ tabel $=1,96)$ dan nilai signifikan $0,000(<0,05)$, berarti factor keluarga berpengaruh signifikan secara parsial terhadap prestasi akademik mahasiswa FITK. Dengan demikian hipotesis penelitian kedua diterima. Hasil penelitian ini di dukung oleh penelitian yang dilakukan oleh Heather cros yang menyatakan bahwa faktor dukungan keluarga dan bantuan keuangan merupakan faktor yang paling penting dalam keberhasilan prestasi akademik mahasiswa.

c. Hipotesis ketiga menyatakan bahwa lingkungan kampusberpengaruh signifikan terhadap prestasi akademik mahasiswa FITK. Dengan nilai t hitung sebesar 2.626 ( $>\mathrm{t}$ tabel

39 Sardiman, A.M. 2007. Interaksi dan Motivasi Belajar Mengajar. Hal:75. Jakarta: PT Raja Grafindo Persada, 
$=1,96)$ dan nilai signifikan 0,009 $(<0,05)$, berarti lingkungan kampusberpengaruh signifikan secara parsial terhadap prestasi akademik mahasiswa FITK. Dengan demikian hipotesis penelitian ketiga diterima. Hasil penelitian ini di dukung oleh penelitian yang dilakukan oleh oki dkk tahun 2012 yaitu Lingkungan kampus meliputi dosen dan sarana prasarana berpengaruh positif dan signifikan terhadap akademik mahasiswa. Hasil penelitian ini juga sejalan dengan penelitian yang dilakukan oleh sangkapan, et.al bahwa lingkungan kampus berpengaruh signifikan terhadap prestasi akademik mahasiswa, demikian juga dengan hasil penelitian irfan affandi.

d. Hipotesis keempat menyatakan bahwa aktif organisasiberpengaruh signifikan terhadap prestasi akademik mahasiswa FITK. Dengan nilai thitung sebesar 8.127 ( $>\mathrm{t}$ tabel $=$ 1,96) dan nilai signifikan $0,000(<0,05)$, berarti aktif organisasiberpengaruh signifikan secara parsial terhadap prestasi akademik mahasiswa FITK. Dengan demikian hipotesis penelitian keempat diterima. Hasil penelitian ini sejalan dengan penelitian yang telah dilakukan oleh oki dkk tahun 2012 yaitu Aktif berorganisasi berpengaruh positif kuat dan signifikan terhadap prestasi akademik mahasiswa.

Berdasarkan hasil penelitian yang diperoleh bahwa semua variabel bebas yaitu motivasi, faktor keluarga, lingkungan kampus dan aktif organisasi berpengaruh positif dan signifikan terhadap prestasi akademik mahasiswa FITK. Sedangkan faktor yang paling dominan yang mempengaruhi prestasi akademik mahasiswa FITK adalah motivasi. Oleh sebab itu pihak pengelola jurusan maupun fakultas perlu senantiasa memotivasi mahasiswa.

\section{PENUTUP}

\section{SIMPULAN}

Berdasarkan hasil penelitian dan pembahasan maka dapat disimpulkan sebagai berikut:

a. Terdapat pengaruh signifikan antara motivasi terhadap 
prestasi akademik mahasiswa FITK. Hal ini dibuktikan dengan nilai t hitung dari variabel motivasi $(55,654>$ 1,96) dengan nilai signifikansi sebesar $0,000<0,05$, berarti motivasi berpengaruh signifikan secara parsial terhadap prestasi akademik mahasiswa FITK. Dengan demikian hipotesis penelitian pertama diterima.

b. Terdapat pengaruh yang signifikan antara faktor keluarga dengan prestasi akademik mahasiswa FITK. Hal ini dapat dibuktikan dengan nilai $\mathrm{t}$ hitung sebesar 11,355 ( $>\mathrm{t}$ tabel $=1,96)$ dan nilai signifikan $0,000(<0,05)$, berarti faktor keluarga berpengaruh signifikan secara parsial terhadap prestasi akademik mahasiswa FITK. Dengan demikian hipotesis penelitian kedua diterima.

c. Terdapat pengaruh yang signifikan antara lingkungan kampus dengan prestasi akademik mahasiswa FITK. Hal ini dapat dibuktikan dengan nilai thitung sebesar 2.626 ( $>$ t tabel $=1,96)$ dan nilai signifikan 0,009 $(<0,05)$, berarti lingkungan kampusberpengaruh signifikan secara parsial terhadap prestasi akademik mahasiswa FITK. Dengan demikian hipotesis penelitian ketiga diterima.

d. Terdapat pengaruh signifikan antara aktif organisasidengan prestasi akademik mahasiswa FITK. Dengan nilai t hitung sebesar 8.127 ( $>\mathrm{t}$ tabel $=1,96$ ) dan nilai signifikan $0,000(<0,05)$, berarti aktif organisasi berpengaruh signifikan secara parsial terhadap prestasi akademik mahasiswa FITK.

\section{Saran-saran}

Berdasarkan hasil penelitian dan simpulan diatas maka dapat diberikan saran yaitu untuk meningkatkan prestasi akademik mahasiswa pihak pengelola jurusan maupun fakultas perlu senantiasa memotivasi mahasiswa. Upaya yang dapat dilakukan diantaranya mengkondisikan supaya mahasiswa tetap belajar walaupun mereka sudah memiliki nilai IPK kategori tinggi; belajar bukan hanya untuk menghadapi ujian; memotivasi mahasiswa yang pernah mengalami kegagalan. 


\section{DAFTAR PUSTAKA}

Affandi, Irfan. 2011. Faktor- Faktor yang Mempengaruhi Prestasi Belajar Mahasiswa Dalam Mata Kuliah Pemeriksaan Akuntansi II (Studi Empiris Pada Mahasiswa Akuntansi UPN "Veteran" Jawa Timur)". Skripsi. Fakultas Ekonomi Universitas Pembangunan Nasional "Veteran" Jawa Timur.

Arikunto, Suharsimi. 2006. Metode Penelitian Suatu Pendekatan Praktik. Jakarta: PT. Rineka Cipta.

Budiyono. 2004. Statistika Dasar Untuk Penelitian. Surakarta: Universitas Sebelas Maret.

Dalyono,M. 1997. Psikologi Pendidikan. Jakarta: PT.Rineka Cipta

Depdikbud. 1990. Kamus Besar Bahasa Indonesia. Jakarta: Balai Pustaka. hal. 700

Farooq, M.S, A.H. Chaudhry, M. Shafiq, G. Berhan. 2011. Factors Affecting Students' Quality Of Academic Performance: A Case Of Secondary School Level. Journal of Quality and Technology Management Volume VII, Issue II, December, 2011, Page 0114

Faridi, Achmad. 2002. Hubungan sarapan pagi dengan kadar glukosa darah dan konsentrasi belajar pada siswa SD. Skripsi. Bogor: GMSK Faperta IPB

Ferdinand, Augusty. 2006. Metode Penelitian Manajemen. 1 ed. Penerbit Fakultas Ekonomi, UNDIP, Semarang.

Ghozali, Imam. 2005. Aplikasi Analisis Multivariate dengan Program SPSS. 3 Ed. Semarang, Badan Penerbit Universitas Diponegoro.

Halim M. 2009. Identifikasi Faktor-Faktor yang Berperan Terhadap Pencapaian Indeks Prestasi Kumulatif Mahasiswa. Departemen Statis- 
tika IPB [Skripsi] Bogor: Jurusan Statistika FMIPA IPB.

Hamzah.B.Uno. 2009. Teori Motivasi dan Pengukurannya Analisis di Bidang Pendidikan. Hal.1. Jakarta:PT.Bumi Aksara

Heather Cros. 2011. Exploring Achievement: Factors Affecting Native American Colleges Student Success. An Applied Research Project. Submitted to the Department of Political Science Texas State University In Partial Fulfillment for the Requirements for the Degree of Masters of Public Administration

Hildayati, Marya. 2002. Penelusuran Faktor-faktor yang Mempengaruhi Prestasi Akademik Mahasiswa Semester I Universitas Ibnu Khaldun Bogor. Skripsi. Bogor: Jurusan statistika FMIPA IPB.

Ilyas. 2004. Pengaruh Komunikasi Orang Tua Terhadap Prestasi Belajar Siswa Pada MTsN Model Makassar. Tesis. Makassar: Universitas Hasanuddin

Irfan Mushtaq \& Shabana Nawaz Khan. 2012. Judul: Factors Affecting Students' Academic Performance. Global Journal of Management and Business Research.Volume 12 Issue 9 Version 1.0 June 2012.

Kamaluddin, R. 2005. Intelegensia Berprestasi. http:/ / www.e-psikologi.com/intelegensia/ma30/html.

Kuh et al. 2006. What Matters to Student Success: A Review of the Literature, Commissioned Report for the National Symposium on Postsecondary Student Success.

Kusumastuti, Tri Laswi. 2010. Hubungan antara Tingkat Pendidikan dan Penghasilan Orang Tua dengan Prestasi Belajar IPA Semester Satu Siswa Kelas Tujuh SMP Cinde Semarang Tahun Pelajaran 2010/2011.Penelitian Tindakan Kelas. Semarang. Diakses 23 April 2011 dalam situs web: http://www.scribd. com/doc/55874141/Hubungan-Antara-Tingkat-PendidikanDan-Penghasilan-Orang-Tua.

Lidia, Susi. 2008. Pngaruh Pola Asuh Orang Tua dan Disiplin Belajar Terhadap Prestasi Belajar Ekonomi Siswa Kelas VIII SMP Negeri 5 
Brebes Tahun Ajaran 2007/2008. Skripsi. Surakarta: UMS

Muhibbin Syah. 2008. Psikologi Pendidikan dengan Pendekatan Baru. Hal.138. Bandung:Remaja Rosdakarya

Muhibbin Syah. 2010. Psikologi Pendidikan. Bandung: PT Remaja Rosdakarya

Ngalim Purwanto. 2000. Psikologi Pendidikan. Hal:84. Bandung: PT Remaja Rosdakarya

Oemar Hamalik. 1992. Psikologi Belajar. Bandung: Sinar Baru. hlm. 173

Riduwan. 2010. Skala Pengukuran Variabel-Variabel Penelitian. Bandung: Alfabeta.

Sagita Adjani dan Helmy Adam. 2008. Faktor-faktor yang Mempengaruhi Prestasi Belajar Mahasiswa Pada Mata Kuliah Pengantar Akuntansi. Skripsi. Universitas Brawijaya

Sampoerno PD. 2002. Analisis kualitas Mahasiswa dalam Pencapaian Pendidikannya dengan Menggunakan Metode Partial Least Squares. Studi kasus: Mahasiswa jurusan Matematika FMIPA Universitas Jakarta [Tesis]. Bogor: Program Pasca Sarjana. IPB

Sangkapan, Jedsarid dan Laeheem, Kasetchai. 2011.Factors Affecting Students Academic Achievement into Probation Status at Prince of Songkla University. The 3rd International Conference on Humanities and Social Sciences. April 2, 2011. Faculty of Liberal Arts, Prince of Songkla University Proceedings- Community Empowerment.

Sarwono, jonathan \& Budiono, herlina. 2012. Statistik Terapan: Aplikasi untuk Riset Skripsi, Tesis dan Disertasi. Hal:189 Jakarta: PT.Elex Media Komputindo

S.F. Habeyb. Kamus Populer, (Jakarta: Nurani, 1983), Cet., Ke-20. h., 296

Slameto. 2003. Belajar dan Faktor-Faktor yang Mempengeruhinya. hal:61. Jakarta: Rineka Cipta 
1995. Belajar dan Faktor-faktor yang Mempengaruhinya. Jakarta: PT Rineka Cipta . 1991. Evaluasi Pendidikan. Jakarta: Bumi Aksara

Soekirman. 1988. Kebijakan Pangan dan Gizi serta Upaya Peningkatan Kualitas Hidup. Gizi Indonesia

Sugiyono. 2008. Metode Penelitian Kuantitatif, Kualitatif dan RED. Bandung: Alfabeta.

Sugiyono. 2010. Metode Penelitian Kuantitatif, Kualitatif dan R \& D. Bandung: PT. Alfabeta.

Sukmadinata, Nana Syaodih. 2005. Metode Penelitian Pendidikan. Bandung: PT Remaja Rosdakarya Offset.

Suryabrata, Sumadi. 2006. Psikologi Pendidikan. Jakarta: PT Raja Grafindo Persada.

Sutama. 2010. Metode Penelitian Pendidikan Kuantitatif, Kualitatif, PTK, $R \mathcal{E D}$. Surakarta: Fairuz Media.

Syaiful Bahri Djamarah. 2002. Psikologi Belajar. Jakarta: PT Rineka Cipta. hlm. 114

Udiyono. 2011. Pengaruh Motivasi Orangtua, Kondisi Lingkungan Dan Disiplin Belajar Terhadap Prestasi Akademik Mahasiswa. Magistra No. 75 Th. XXIII Maret 2011.ISSN 0215-9511

Umar Tirtarahardja \& La Sulo. 2005. Pengantar Pendidikan. Jakarta: PT Rineka Cipta. hlm.168

W.S. Winkel. 2007. Psikologi Pengajaran. Yogyakarta: Media Abadi Winkel. 1987. Psikologi Pengajaran. Jakarta: PT. Gramedia hlm. 92 Yuniah. 2006. Faktor-faktor Yang Berpengaruh Terhadap Prestasi Akademik Mahasiswa TPB IPB Dengan Metode CHAID. Skripsi. Departemen Statistika Fakultas Matematika Dan Ilmu Pengetahuan Institut Pertanian Bogor. 